\title{
UPLIFT CINEMA
}





\title{
UPLIFT CINEMA
}

The Emergence of African American Film and the Possibility of Black Modernity

\author{
ALLYSON NADIA FIELD
}


(C) 2015 DUKE UNIVERSITY PRESS. All rights reserved.

Printed in the United States of America on acid-free paper @

Typeset in Minion Pro by Tseng Information Systems, Inc.

Interior design by Courtney Leigh Baker.

Library of Congress Cataloging-in-Publication Data

Field, Allyson Nadia, 1976-

Uplift cinema : the emergence of African American film and the possibility of black modernity / Allyson Nadia Field.

pages $\mathrm{cm}$

Includes bibliographical references and index.

ISBN 978-0-8223-5907-4 (hardcover : alk. paper)

ISBN 978-0-8223-5881-7 (pbk. : alk. paper)

ISBN 978-0-8223-7555-5 (e-book)

1. African Americans in the motion picture industry-History-2oth century.

2. African Americans in motion pictures-History-2oth century. I. Title.

PN1995.9.N4F54 2015

$791.43^{\prime} 652996073-\mathrm{dc} 23 \quad 2014046259$

Cover art: Film still courtesy A/V Geeks.

Duke University Press gratefully acknowledges Harvard Studies in Comparative Literature, which provided funds toward the publication of this book. 
for Werner 
